\title{
Response of Pocillopora verrucosa to corallivory varies with environmental conditions
}

\author{
Hunter S. Lenihan ${ }^{1, *}$, Peter J. Edmunds ${ }^{2}$ \\ ${ }^{1}$ Bren School of Environmental Science and Management, University of California, Santa Barbara, \\ California 93106-5131, USA \\ ${ }^{2}$ Department of Biology, California State University, Northridge, California 91330-8303, USA
}

\begin{abstract}
We wounded Pocillopora verrucosa to simulate injury caused by fish corallivores, and then evaluated impacts of this damage on coral performance under different temperatures (26.6 and $29.6^{\circ} \mathrm{C}$ ) and flow speeds ( 6 and $21 \mathrm{~cm} \mathrm{~s}^{-1}$ ) in microcosms. Colony growth (weight), photosynthetic efficiency (maximum dark-adapted quantum yield of PSII, $F_{\mathrm{v}} / F_{\mathrm{m}}$ [where PSII is Photosystem II, $F_{\mathrm{v}}$ variable fluorescence and $F_{\mathrm{m}}$ maximum fluorescence yield in the dark]), and the healing of lesions were measured during 2 replicate $10 \mathrm{~d}$ trials. Injury caused growth to increase in 3 of 4 treatments: high flow, high temperature; low flow, high temperature; and low flow, low temperature. However, growth was greatest for uninjured corals in the high-flow, low temperature treatment, which appears to provide optimal conditions for $P$. verrucosa (when not injured). Temperature alone had little effect on growth but influenced $F_{\mathrm{v}} / F_{\mathrm{m}}$, as did flow; $F_{\mathrm{v}} / F_{\mathrm{m}}$ was $5 \%$ greater at $26.6^{\circ} \mathrm{C}$ than $29.6^{\circ} \mathrm{C}$, and $3 \%$ higher at $21 \mathrm{~cm} \mathrm{~s}^{-1}$ than $6 \mathrm{~cm} \mathrm{~s}^{-1}$. Injury had little effect on $F_{\mathrm{v}} / F_{\mathrm{m}}$, and neither temperature nor flow affected the rate of healing that occurred at 17 to $25 \%$ of the lesion area in $10 \mathrm{~d}$. Results from a field experiment, in which growth of $P$. verrucosa was tested as a function of flow speed $\left(\sim 14 \mathrm{~cm} \mathrm{~s}^{-1}\right.$ versus $\sim 3 \mathrm{~cm} \mathrm{~s}^{-1}$ ) and fish predation (predators versus no predators), but not temperature, supported results of the microcosm experiment. Growth was greatest for corals in the high-flow, no predator treatment, and relatively high for injured corals in low flow. Together, these results suggest that $P$. verrucosa, a common branching coral, prioritizes overall growth over repair when injured by fish feeding, which differs from the outcome observed in a companion study in which juvenile colonies of massive Porites were subjected to similar injuries.
\end{abstract}

KEY WORDS: Coral $\cdot$ Predation $\cdot$ Flow $\cdot$ Temperature $\cdot$ Scleractinia

Resale or republication not permitted without written consent of the publisher

\section{INTRODUCTION}

The foundation of modern ecology includes research conducted in marine ecosystems that reveals how abiotic conditions influence biotic interactions, including competition, predation, and positive relationships (e.g. Connell 1961a,b, Paine 1966, Dayton 1971, Bertness \& Callaway 1994). Similar physical-biological interactions occur in terrestrial (Crawley 1985, Belsky et al. 1989), freshwater (Cardinale et al. 1997), and estuarine (Lenihan \& Peterson 1998, Leonard et al. 1998) ecosystems. A subset of this work focused on non-fatal injuries caused by herbivory ('incomplete grazing') and predation ('partial predation') that influence the performance of prey (Peterson \& Quammen 1982, Zajac 1985) under varying environmental conditions (Lincoln et al. 1993, Powers \& Peterson 2000, Powers \& Kittinger 2002). Partial predation can trigger complex responses in prey that alter demographic performance, especially growth (Skilleter \& Peterson 1994) and reproductive output (Strauss \& Agrawal 1999).

Corals are frequently attacked and injured by corallivorous fishes and invertebrates (Moran 1986, Turner 1994, Rotjan \& Lewis 2008), and corallivory appears to be an important factor regulating coral abundance, distribution, and fitness, especially for the most preferred coral taxa, Acropora, Pocillopora, and Porites (Cole et al. 2008). Partial predation of corals has prob- 
ably played a significant role in coral evolution through its effect on morphology, physiology, and ecological adaptation (Wood 1998). Such injuries can reduce coral performance (Frydl 1979, Neudecker 1979, Cox 1986, Rotjan \& Lewis 2009), in part because corals may allocate limited resources to repair injuries and regenerate lost tissue (Hall 2001, Henry \& Hart 2005). The regeneration of tissue is affected by other intrinsic factors besides resources, such as the innate capacity for regeneration (Meesters et al. 1997), translocation within the colony (Oren et al. 2001), disease (Aeby \& Santavy 2006), and the capacity for the induction of biochemical responses to the initial disturbance (Gochfeld 2004) (reviewed in Henry \& Hart 2005). Extrinsic factors, such as the abiotic conditions, can also affect the healing of coral tissues by limiting the availability of energetic and cellular resources necessary for regeneration (Henry \& Hart 2005). Competition between regrowing coral tissue and taxa that have colonized the lesion can also affect the rate of recovery (Titlyanov et al. 2005). In general, however, the ways in which corals respond in terms of individual performance to partial predation under varying environmental conditions has not been sufficiently assessed (Cole et al. 2008; but see Lester \& Bak 1985, Nagelkerken et al. 1999, Kramarsky-Winter \& Loya 2000).

In a study that served as a companion to the present analysis (Edmunds \& Lenihan 2010), we found that juvenile colonies of massive Porites spp. (henceforth Porites) healed following a single bite-like injury, and that growth rates were higher for injured than uninjured colonies under relatively high flow speed $\left(21 \mathrm{~cm}^{-2}\right)$ and low temperature $\left(27^{\circ} \mathrm{C}\right)$. The injuries to massive Porites spp. (henceforth Porites) were inflicted with pliers, and were designed to simulate fish corallivores in the excavating functional feeding group (sensu Bellwood \& Choat 1990). We hypothesized that the response to injury was a result of the ability of poritid corals to allocate resources towards healing of damaged areas (Hall 1997). Further, we speculated that the capacity to translocate resources in a source-sink model (e.g. Pearse \& Muscatine 1971) would be accentuated in corals with thick tissues that permeate deeply (1.6 to $5.2 \mathrm{~mm}$; Edmunds 2008) into the perforate skeleton and contain extensions of the gastrovascular cavity through which metabolites are moved (Oren et al. 2001). Through this mechanism, superficial wounds that remove the outer layer of tissue (but not the full thickness) are likely to heal faster than severe wounds that excise the entire tissue depth, because superficial wounds can heal both marginally (i.e. from the edge of the wound) and basally (i.e. from the abraded tissue in the base of the wound) (Henry \& Hart 2005). The inclusion in abraded tissue of calicoblastic ectoderm and gastrovascular canals makes it likely that new skeleton can be deposited directly within the wound, thereby supporting rapid increases in weight of damaged corals. Such an outcome is reminiscent of the 'compensatory growth' shown by some plants in response to herbivores (McNaughton 1983). In our earlier work, we found that the healing of injured Porites was modified by temperature, with tissue regeneration and growth greater at $27^{\circ} \mathrm{C}$ than $30^{\circ} \mathrm{C}$ (Edmunds \& Lenihan 2010), probably because the lower temperature is close to the thermal optimum for a variety of physiological processes in corals (Buddemeier \& Kinzie 1976, Iglesias-Prieto et al. 1992, Edmunds 2005).

Following our analysis of the effects of damage on massive Porites, here we expand our study to branching Pocillopora spp. (henceforth Pocillopora) based on the rationale that a dissimilar response might be anticipated given the dissimilar morphologies and life-history strategies of the 2 taxa. Our reasoning for suspecting dissimilar responses between the taxa was fourfold. First, Pocillopora has an imperforate skeleton with tissue constrained to the outer surface, and therefore it is easy for a fish bite to remove the entire tissue layer and force subsequent healing to occur by marginal processes alone. Second, with only superficial tissue it is possible that the translocation of metabolites necessary for healing could be slowed by a gastrovascular system that is less extensive in Pocillopora than Porites. Third, the morphology of Pocillopora is likely to affect the response to corallivory, because growth tends to occur apically in branching corals (Allemand \& Benazet-Tambutte 1996), where Pocillopora is bitten most frequently (Cole et al. 2008), but more uniformly across the colony in massive corals such as Porites (Barnes \& Devereux 1988). Finally, Pocillopora and massive Porites represent contrasting life-history strategies, with Pocillopora favoring an opportunistic ('weedy') strategy, with high rates of growth and reproduction and rapid generation time (Ayre et al. 1997), while massive Porites displays relatively slow growth, high resistance to physical stress, and slow rates of population turnover (Done 1987, Lough \& Barnes 2000). Together, these characteristics suggest that Pocillopora may be less well suited to enduring partial predation than massive Porites. Our decision to examine the effects of partial predation on Pocillopora in the present study was also driven by Pocillopora's ecological relevance in corallivore-coral interactions. Recent reviews suggest that while many corallivores prey on both massive Porites and branching Pocillopora (Cole et al. 2008, Rotjan \& Lewis 2009), a higher proportion of predators preferred Pocillopora (22\%) to Porites ( $8 \%$ ) as their major prey (Cole et al. 2008). In contrast, we recently found in a demographic study conducted in the back reef of Moorea, French Polynesia-the same system as that studied in this paper- 
that 20 to $43 \%$ of juvenile Pocillopora and 17 to $43 \%$ of juvenile Porites (10 to $44 \mathrm{~mm}$ in diameter) were bitten and injured by corallivorous fishes, depending on where they were located and on what substrate type they were found (H. Lenihan unpubl. data). Acropora generally appears to be the most preferred coral taxa (55\%; Cole et al. 2008).

The objective of the present study was to test the hypothesis that growth rates of small colonies of Pocillopora verrucosa are reduced through injury associated with partial predation by fishes, but that the response varies with seawater temperature and water flow, both of which vary across reefscapes and influence coral demographic rates (Lenihan et al. 2008). As a means to this end, microcosms were used to expose corals to combinations of treatments consisting of physical injury designed to simulate predation by certain fishes, temperatures, and flow regimes. To test whether the results of the laboratory experiment help predict the response of $P$. verrucosa to corallivory under natural environmental conditions, we conducted a field experiment in which we examined the growth of juvenile $P$. verrucosa as it varied as a function of biotic and abiotic factors. Specifically, we examined coral growth under varying regimes of fish predation (controlled by exclusion cages) and flow speed (controlled by placing corals on natural substrata differing in exposure to flow speeds). We explore the contrasting responses observed for branching $P$. verrucosa (in this study) and massive Porites (Edmunds \& Lenihan 2010) to identify general ecophysiological mechanisms by which corals may respond to corallivory under varying environmental conditions.

\section{MATERIALS AND METHODS}

Laboratory study. A laboratory experiment was conducted during April and May 2008 at the University of California-Berkeley Richard B. Gump South Pacific Research Station in Moorea $\left(17^{\circ} 30^{\prime} \mathrm{S}, 1^{\circ} 9^{\circ} 50^{\prime} \mathrm{W}\right)$, French Polynesia. This experiment was designed to test the prediction that injuries similar to those caused by corallivorous fishes in the excavating functional group (Bellwood \& Choat 1990) influence the growth of Pocillopora verrucosa, but that the response varies with abiotic conditions. Specifically, we tested whether water motion ('flow speed') and temperature influenced growth, maximum dark-adapted quantum yield of PSII, $F_{\mathrm{v}} / F_{\mathrm{m}}$ [where PSII is Photosystem II, $F_{\mathrm{v}}$ is variable fluorescence and $F_{\mathrm{m}}$ is maximum fluorescence yield in the dark] a measure of photosynthetic efficiency; Maxwell \& Johnson 2000), and the sizes of the sites of injuries (hereafter 'lesions). $F_{\mathrm{v}} / F_{\mathrm{m}}$ was examined because it directly quantifies the efficiency with which PSII harvests light, and indirectly assesses the capacity to fix carbon through photosynthesis (Maxwell \& Johnson 2000). We reasoned that a metric (i.e. $F_{\mathrm{v}} / F_{\mathrm{m}}$ ) evaluating the capacity to supply organic carbon by photosynthesis and drive changes in concentration of dissolved inorganic carbon would be helpful in identifying a mechanism causing variation in growth and healing of corals (Furla et al. 2000, Henry \& Hart 2005). We used small branches (13 to $42 \mathrm{~mm}$ long; 'nubbins') of $P$. verrucosa as a model system; we collected these from 3 to $4 \mathrm{~m}$ depth in the back reef of Moorea. These corals were allocated to 1 of 2 groups: one was left unmanipulated, and the other was injured with pliers in a treatment designed to simulate the effects of excavating corallivores. The 2 groups of corals were incubated in 2 indoor tanks that were maintained at different temperatures and contained 2 flow speed treatments. The experiment was replicated with different corals in 2 sequential trials ( $5 \mathrm{~d}$ apart) to exploit temporal replication and address some of the limitations of a pseudoreplicated design in which multiple corals were incubated in each tank.

The tanks were $200 \times 95 \mathrm{~cm}$, and filled to $14 \mathrm{~cm}$ depth with unfiltered seawater pumped from Cook's Bay. When filled, these tanks contained 2661 of seawater that was continuously refreshed at $11 \mathrm{~min}^{-1}$, with the volume replaced within $5 \mathrm{~h}$. Each tank was fitted with a chiller and heater that maintained the temperature at either $\sim 27$ or $\sim 29^{\circ} \mathrm{C}$, and was illuminated on a 12:12 h light:dark cycle with two $1000 \mathrm{~W}$ metal halide lamps (Sylvania BT37, Metalarc). The higher temperature was close to the ambient seawater temperature when the 2 trials of the experiment were completed in April/May 2008, and both temperatures spanned the normal range that occurs in the shallow back reef of Moorea (Lenihan et al. 2008, P. Edmunds unpubl. data). The lamps were screened with neutral density mesh to $\sim 700 \mu \mathrm{mol}$ photons $\mathrm{m}^{-2} \mathrm{~s}^{-1}$ (measured with a LiCor LI 193SA), which, although lower than the highest irradiance recorded at the collection site at noon on a sunny day, ensured that the daily integrated irradiance $\left(\sim 30 \mathrm{E} \mathrm{m}^{-2} \mathrm{~d}^{-1}\right.$ supplied as a square function over $12 \mathrm{~h}$ ) was close to that experienced in the field (supplied as a sine function over $12 \mathrm{~h}$ with a maximum of $1200 \mu \mathrm{mol}$ photons $\mathrm{m}^{-2} \mathrm{~s}^{-1}$ ). Two $170 \mathrm{~cm}$ long raceways were constructed from PVC sheets in each tank, and each was fitted at one end with 1 or 2 aquarium pumps (2600 $\mathrm{l} \mathrm{h}^{-1}$; Rio Aqua) that created either a low- or a high-flow treatment, respectively. The outflow from each pump passed through a $5 \mathrm{~cm}$ long flow straightener to reduce turbulence, and was adjusted with a valve to achieve target flow speeds of about 5 and $20 \mathrm{~cm} \mathrm{~s}^{-1}$. These flow speeds were selected to simulate the differences in flow utilized in the field experiment by growing corals on top of bommies (dead or partially 
dead coral structures; see 'Field experiment' for definition) or lower down on the adjacent benthos (Lenihan et al. 2008).

The corals were collected on 12 April 2008 (Trial 1) and 27 April 2008 (Trial 2) from the back-reef hard substrate ('pavement') at $3 \mathrm{~m}$ depth. For each trial, 80 short branches of Pocillopora verrucosa were broken from colonies that were selected haphazardly, and one branch was broken from each colony to increase the likelihood that each represented a unique coral genotype. The freshly collected branches were returned to the lab, where the apices were trimmed to a length of 13 to $42 \mathrm{~mm}$ using bone shears. Trimming was accomplished with care to ensure that the branch apices were undamaged and were of similar, digitate shapes. The branches were glued (with Z Spar, A788 epoxy) to the tops of pieces of individually numbered PVC pipe $(\sim 2 \mathrm{~cm}$ long and $1.5 \mathrm{~cm}$ diameter), the bottoms of which were fitted with a $6 \mathrm{~mm}$ diameter nylon screw. This procedure created experimental units-with corals attached to the PVC with minimal contact between the coral tissue and the epoxy - that could be inserted into PVC racks drilled to accept the screw attached to the base of the pipe; each rack held 20 corals upright in a linear array.

The prepared corals were inserted into the PVC racks and left to recover for $\sim 36 \mathrm{~h}$ in the tank held at ambient temperature and illuminated for $12 \mathrm{~h}$ each day at $700 \mu \mathrm{mol}$ photons $\mathrm{m}^{-2} \mathrm{~s}^{-1}$. Following recovery, 40 of the corals in each trial were exposed to a simulated effect of fish predation achieved by scraping the colonies with $10 \mathrm{~mm}$ wide, snub-nose pliers. The scrapes were made in haphazard locations on the colonies, and the pliers were applied to create a pair of rectangular lesions $\sim 12 \times 8 \mathrm{~mm}$ in size. The pliers were rinsed in seawater between colonies to reduce the chance of contamination, and the sizes of the lesions (length $\times$ width) were recorded with calipers $( \pm 1 \mathrm{~mm})$. The scraping removed superficial skeleton to 1 to $2 \mathrm{~mm}$ depth, as well as the entire tissue layer, and caused damaged areas similar in dimension to those seen naturally on Pocillopora on the reefs of Moorea (H. Lenihan unpubl. data). While our experimental approach assessed the response to injury in nubbins that had already been broken from donor colonies, we rationalized this approach in 2 ways. First, any effect of the fracturing necessary to collect the corals would be consistent among all nubbins and independent of the lesions created on some of the corals to simulate corallivory. Second, the fractured surface resulting from collection was immediately placed into epoxy to prepare the corals as upright nubbins, and, therefore, there was no potential for the tissue to heal across this surface (as was the case with the experimental lesions).
Following preparation, the corals were buoyant weighed (Davies 1989) so that their growth (change in weight) could be determined; they were then returned to the racks in the tank held at ambient temperature. Following $3 \mathrm{~h}$ of darkness (beginning at 18:30 h), the photosynthetic efficiency of the corals was assessed as $F_{\mathrm{v}} / F_{\mathrm{m}}$ using a Diving-PAM (Walz) fitted with an $8 \mathrm{~mm}$ diameter probe and operated with constant settings for all corals. $F_{\mathrm{v}} / F_{\mathrm{m}}$ was measured with the probe held $\sim 5 \mathrm{~mm}$ above the coral tissue, and all measurements were made at haphazard positions on the coral surface and, for the injured corals, outside the area of damage. Finally, the corals were allocated randomly to each of 4 racks, with 20 undamaged and 20 damaged colonies on each rack. The experimental incubation began the following morning ( $\sim 66 \mathrm{~h}$ after collection), on either 15 April (Trial 1) or 30 April (Trial 2), with the allocation of the racks at random to either the high-flow or the low-flow speed treatments within the ambient and the cool tanks. Thereafter, each trial was maintained for $10 \mathrm{~d}$ until its conclusion at 20:00 h on either 25 April (Trial 1) or 10 May 2008 (Trial 2).

Throughout the experiment, the seawater temperature was recorded every 30 min with loggers (Hobo Aquapro II, Onset Computer Company), and light intensity and water transport were measured periodically. The light intensity was measured using a $4 \pi$ quantum sensor (LiCor LI 193SA) that was positioned beneath the water at 3 positions along each of the 2 raceways in each tank. The water motion within the raceways was assessed as net water transport, which was measured by timing the repeated passage of neutrally buoyant particles along a known distance. This technique was not intended to measure the absolute flow speed experienced by each coral, but instead, characterized the net movement of water along the raceways. As the water motion varied along the raceway, and upstream corals affected the flow around downstream corals, the position of all corals within each raceway was randomized daily. Randomization was achieved by removing the corals from the racks each morning and replacing them in the same racks but at new, randomly selected positions; this was accomplished without touching the coral tissue or removing the corals from the seawater.

At the conclusion of the experiment, $F_{\mathrm{v}} / F_{\mathrm{m}}$ was again measured after $3 \mathrm{~h}$ of dark adaptation, the sizes of the damage lesions were measured and the buoyant weights recorded. All measurements were completed in an identical manner to the initial measurements. The changes in buoyant weight were converted to dry weight assuming that the skeletal aragonite had a density of $2.93 \mathrm{~g} \mathrm{~cm}^{-3}$ (Jokiel et al. 1978). Following the final weighing, the corals were dried at $60^{\circ} \mathrm{C}$, and their tissue areas measured using the wax dipping tech- 
nique (Stimson \& Kinzie 1991) to normalize growth rates to area $\left(\mathrm{mg} \mathrm{cm} \mathrm{cm}^{-2} \mathrm{~d}^{-1}\right)$; the comparison of these growth rates among treatments assumes that they were linear over the study.

Field experiment. We conducted a field experiment in January 2008 to test whether the growth of juvenile Pocillopora verrucosa varied with flow speed and partial predation in the back reef of Moorea. The experiment was conducted in a mid-lagoon area, located $\sim 200 \mathrm{~m}$ from the reef crest, at $3 \mathrm{~m}$ depth near Cook's Bay. The mid-lagoon is dominated by pavement together with patches of Porites lobata, Porites australiensis, Porites lutea, and Porites rus. These coral structures, referred to as 'bommies', can reach $>3 \mathrm{~m}$ diameter and >2 $\mathrm{m}$ height, and are often colonized by smaller branching corals, other invertebrates, and algae. In a recent demographic survey of branching corals in the back reef of Moorea, we found that growth and survival of juvenile Pocillopora verrucosa (colonies $<40 \mathrm{~mm}$ diameter) was higher on bommies compared with the adjacent seafloor, because bommies provide access to increased water flow (Lenihan et al. 2008), a greater flux of zooplankton (Alldredge \& King 2009), and reduced rates of sedimentation (Lenihan et al. 2008). We have found only minor differences in temperature and light between the seafloor and the tops of bommies in this location (Lenihan et al. 2008), and differences in these factors are probably not responsible for the observed differences in coral performance on these 2 substrate types.

On 2 January 2008, 48 juvenile Pocillopora verrucosa colonies (30 to $35 \mathrm{~mm}$ diameter) were collected from the back reef near Cook's Bay, and transported to seawater tables at the research station. After $24 \mathrm{~h}$, they were buoyant weighed, and within an additional $24 \mathrm{~h}$, returned to the reef, where they were placed on the tops of bommies ( $\sim 1 \mathrm{~m}$ in height at $\sim 2 \mathrm{~m}$ water depth) or the adjacent seafloor ( $3 \mathrm{~m}$ water depth). These 2 locations were selected to provide a natural contrast of flow regimes (Lenihan et al. 2008), and corals were allocated at random to each location.

Moorea's back reef supports populations of corallivorous porcupinefish Diodon hystrix (Diodentidae), white-spotted pufferfish Arothon hispidus (Tetradontidae), and orange-striped triggerfish Balistapus undulates (Balistidae) (H. Lenihan unpubl. data) that belong to the excavating functional feeding group (Bellwood \& Choat 1990) that consumes coral tissue as well as underlying skeleton. Butterflyfishes (Chaetodontidae) are also common in this habitat, but most of these fishes eat only the soft tissues of coral and do not remove the underlying skeleton (Bellwood \& Choat 1990; but see Motta 1979). We manipulated the access of corallivorous fishes to our experimental corals by using cages ('no predation' treatment) and cage controls ('predation' treatments, composed of half cages), which we deployed on the tops of bommies. Cages consisted of 6 -sided enclosures $(15 \times 15 \times 15 \mathrm{~cm})$ made of Vexar ${ }^{\circledR}$ plastic ( $1 \mathrm{~cm}$ mesh size), and cage controls were the same design but with 2 sides missing to allow corallivorous fishes access while exposing corals to hydrodynamic conditions similar to those within cages (H. Lenihan unpubl. data). We used this size of cage control (and thus cages), because in a preliminary test we observed D. hystrix, A. hispidus, and B. undulates biting Pocillopora verrucosa corals within the cage controls and leaving distinctive lesions. A no-cage treatment was deemed unnecessary because prior trials revealed no difference in coral growth and intensity of corallivory on corals in cage versus no cage treatments. One replicate coral was placed in each cage or cage control using Z-Spar® marine epoxy, and each pair of cages was attached either to a bommie or the adjacent seafloor $(n=12$ replicates for each of the 2 substrate types). Growth of the corals was measured as change in buoyant weight after $30 \mathrm{~d}$, converted to dry weight using the density of aragonite $\left(2.93 \mathrm{mg} \mathrm{cm}{ }^{3}\right)$, and normalized to area $\left(\mathrm{mg} \mathrm{cm} \mathrm{cm}^{-2} \mathrm{~d}^{-1}\right)$ as determined using the wax dipping technique (Stimson \& Kinzie 1991).

To characterize the flow regimes in the 2 substrata treatments, flow speed and direction were measured on the tops of bommies and on the adjacent seafloor ( $\mathrm{n}=8$ of each type) on 14 January 2008, using an Acoustic Doppler Velocimeter (ADV; $6 \mathrm{MHz}$ Nortek Vector). We measured horizontal current speed, defined as $\sqrt{U^{2}+V^{2}}$, where $U$ and $V$ are the east-west and north-south velocity components, respectively (the sign convention is that east and north are positive), on the top of each bommie and on the adjacent seafloor for a 15 min period. An additional set of flow speed measurements was made in June 2008, in which an ADV was placed on the top of a $1.1 \mathrm{~m}$ tall bommie and another on the adjacent seafloor, and data were collected for a $24 \mathrm{~h}$ period. Data were recorded every second but averaged over 15 min periods. Water temperature was recorded 10 times (about every other day) during the $30 \mathrm{~d}$ experiment with a hand-held thermometer (accuracy $\pm 0.5^{\circ} \mathrm{C}$ ) placed within $10 \mathrm{~cm}$ of the replicate cage and cage control pairs.

Finally, we estimated the abundance of coral predators in the relative vicinity of the field experiment by counting all corallivorous fishes along transect lines located on the forereef (just outside of the lagoon; $250 \mathrm{~m}$ from our experiments; $6 \mathrm{~m}$ water depth), in the back reef (within the lagoon; 10 to $100 \mathrm{~m}$ from the reef crest; 100 to $190 \mathrm{~m}$ from our experiments; $2 \mathrm{~m}$ water depth), and in the mid-lagoon (150 to $250 \mathrm{~m}$ from the reef crest; surrounding our experiments; $3 \mathrm{~m}$ water 
depth). Fish counts were made by scuba divers during early morning daylight hours. Four transects $(50 \mathrm{~m}$ long $\times 4 \mathrm{~m}$ wide) at each site were sampled on each of 2 successive days in austral summer (January 2008) and winter (July 2008). The forereef and back reef generally have higher current speeds and more turbulence (due to swell, waves, and swash) than the mid-lagoon $(H$. Lenihan \& J. Hench unpubl. data), especially during austral summer months when the significant wave height (i.e. the largest onethird of waves) is greatest, and the highest volume of water enters the lagoon through waves breaking over the reef crest. Austral winter months usually have the lowest significant wave height and thus volume of water entering the lagoon $(\mathrm{H}$. Lenihan \& J. Hench unpubl. data).

Statistical approach. To detect differences in growth and $F_{\mathrm{v}} / F_{\mathrm{m}}$ in the microcosm experiment, we used a 3way blocked ANOVA in which injury (injured versus uninjured), flow speed (high versus low), and temperature (high versus low), were orthogonal fixed factors, and trial $(\mathrm{n}=2)$ was the blocking factor. For the change in the size of the lesion (i.e. 'healing'), we compared treatments using a 2-way blocked ANOVA in which flow speed and temperature were crossed, fixed factors, and trial $(\mathrm{n}=2)$ was the blocking factor. A 1-way ANOVA was used to test for differences in initial $F_{\mathrm{v}} / F_{\mathrm{m}}$ between injured and uninjured corals in the laboratory. To detect differences in growth among treatments in the field experiment, we used a 2-way ANOVA, in which substrate type (bommie top versus seafloor) and caging treatment (cages versus cage controls) were crossed, fixed factors.

For the laboratory experiment, a 1-way ANOVA blocked by trial was used to compare light levels among treatments, and a 2-way ANOVA, in which tank and flow treatment were crossed, fixed factors, and trial was the blocking factor, was used to test for differences in water motion. Differences in flow speed and temperature between bommies and the seafloor were compared with 1-way ANOVAs. Before completing the ANOVAs, all data were tested for homogeneity of variances using Cochran's $C$-test. Proportional data were arsine transformed prior to analysis, and post hoc contrasts among treatments were conducted with Student-Newman-Keuls (SNK) tests. Simple linear regression was used to test the relationship between growth rates and flow speed (measured in January 2008) in the field experiment.

\section{RESULTS}

\section{Laboratory experiment}

The microcosms were effective in maintaining the treatments, with seawater temperature remaining almost identical in both trials, and mean light levels differing between trials by only $40 \mu \mathrm{mol}$ photons $\mathrm{m}^{-2}$ $\mathrm{s}^{-1}$ in the high-temperature tank, and $111 \mu \mathrm{mol}$ photons $\mathrm{m}^{-2} \mathrm{~s}^{-1}$ in the low-temperature tank (Table 1). Mean temperature differed between treatment microcosms $\left(26.7\right.$ versus $\left.29.6^{\circ} \mathrm{C} \pm<0.1^{\circ} \mathrm{C} \mathrm{SE}\right)$, but differed by $<0.1^{\circ} \mathrm{C}$ within each microcosm between trials (Table 1). Light intensities were statistically indistinguishable between trials $\left(F_{1,179}=3.07, \mathrm{p}=0.08\right)$ but varied significantly between tanks $\left(F_{1,179}=3.07, \mathrm{p}=\right.$ 0.02 ) due to random effects such as differential aging of bulbs. The difference in light levels between microcosms averaged across trials was trivial in biologically meaningful terms (low-temperature microcosm: $692 \pm$ $25 \mu \mathrm{mol}$ photons $\mathrm{m}^{-2} \mathrm{~s}^{-1}$ versus high-temperature tank: $772 \pm 25 \mu \mathrm{mol}$ photons $\mathrm{m}^{-2} \mathrm{~s}^{-1}$ ). Flow speed (Table 1) varied between flow treatments (i.e. raceways; $F_{1,47}=$ 6.17, $\mathrm{p}=0.02)$ but not with trial $\left(F_{1,47}=1.76, \mathrm{p}=0.19\right)$, tank (i.e. temperature; $F_{1,47}=0.89, \mathrm{p}=0.35$ ), or the interaction between flow treatment and tank $\left(F_{1,47}=\right.$ $0.90, \mathrm{p}=0.35$ ).

The nubbins of Pocillopora verrucosa survived well through the 2 trials, with no mortality, no signs of partial tissue mortality, and normal nighttime polyp expansion. However, at the end of the first trial (but not the second), many of the corals were slightly pale in color, particularly in the high-flow, high-temperature $\left(\mathrm{HH}_{i} 55 \%\right.$ of the corals) and high-flow, low-tempera- 
ture (HL; $50 \%$ ) conditions, and to a lesser extent, in the low-flow, low-temperature (LL; 45\%) and high-flow, low-temperature (HL; 20\%) conditions. Mean $( \pm$ SE) growth rates ranged from $0.46 \pm 0.05 \mathrm{mg} \mathrm{cm}^{-2} \mathrm{~d}^{-1}(\mathrm{LH}$, no predation, Trial 1) to $0.89 \pm 0.16 \mathrm{mg} \mathrm{cm}^{-2} \mathrm{~d}^{-1}$ (HL, no predation, Trial 1), but it did not vary between trials (Table 2). Growth did, however, vary as a function of the interactive effects of injury, flow speed, and temperature (Table 2). The 3-way interaction was signifi-

Table 2. Results of a 3-way, blocked ANOVA comparing the growth in buoyant weight of Pocillopora verrucosa nubbins as a function of injury, flow speed, temperature, and their interaction in the laboratory experiment. Trials, of which there were 2 , was the blocking factor. $\mathrm{n}=10$ replicates per treatment in each trial. I: injury; F: flow speed; T: temperature. Result in bold is significant

\begin{tabular}{|lccccc|}
\hline Source & df & SS & MS & $F$ & $\mathrm{p}$ \\
\hline Trial & 1 & 0.008 & 0.008 & 0.20 & 0.66 \\
$\mathrm{I}$ & 1 & 0.000 & 0.000 & 0.01 & 0.94 \\
$\mathrm{~F}$ & 1 & 0.012 & 0.012 & 0.29 & 0.59 \\
$\mathrm{~T}$ & 1 & 0.076 & 0.076 & 1.85 & 0.18 \\
$\mathrm{I} \times \mathrm{F}$ & 1 & 0.038 & 0.038 & 0.92 & 0.34 \\
$\mathrm{I} \times \mathrm{T}$ & 1 & 0.155 & 0.155 & 3.76 & 0.05 \\
$\mathrm{~F} \times \mathrm{T}$ & 1 & 0.000 & 0.000 & 0.00 & 0.96 \\
$\mathrm{I} \times \mathrm{F} \times \mathrm{T}$ & 1 & 0.208 & 0.208 & 5.05 & $\mathbf{0 . 0 3}$ \\
Error & 142 & 5.841 & 0.041 & & \\
\hline
\end{tabular}

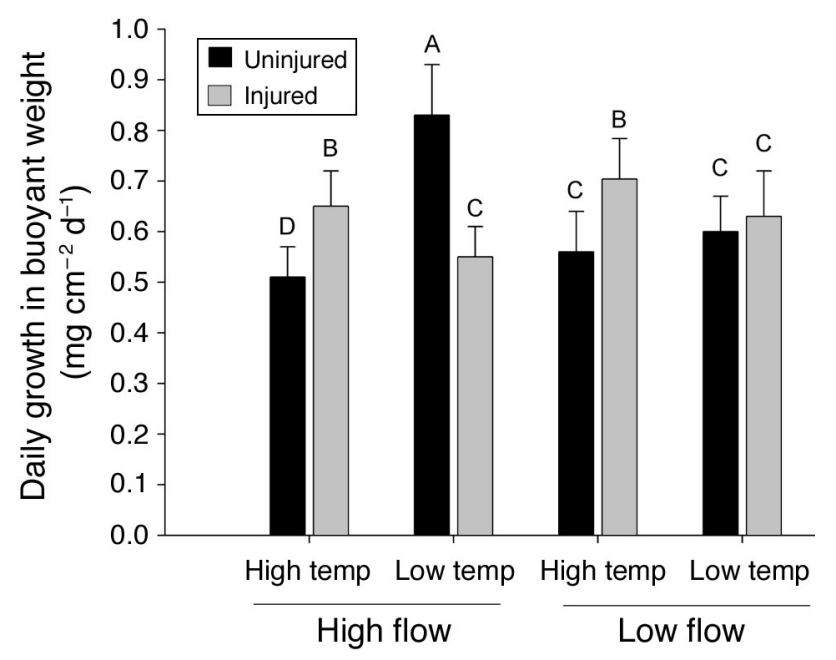

Fig. 1. Pocillopora verrucosa. Growth after $10 \mathrm{~d}$ incubation at high flow and high temperature $(\mathrm{HH})$, high flow and low temperature (HL), low flow and high temperature (LH), and low flow and low temperature (LL) (summarized in Table 1), for corals that were injured or uninjured in 2 replicate trials (Trial 1 or Trial 2); means (+SE) shown are pooled from 2 trials ( $\mathrm{n}=20$ for each bar). A-D: results of Student-Newman-

Keuls (SNK) post hoc tests $(\mathrm{A}>\mathrm{B}>\mathrm{C}>\mathrm{D})$ at $\mathrm{p}<0.05$
Table 3. Results of a 3-way, blocked ANOVA comparing dark adapted yield (variable fluorescence/maximum fluorescence yield in the dark, $F_{\mathrm{v}} / F_{\mathrm{m}}$ ) of Pocillopora verrucosa nubbins as a function of injury, flow speed, temperature, and their interaction in the laboratory experiment. Trials, of which there were 2 , was the blocking factor. $\mathrm{n}=10$ replicates per treatment in each trial. I: injury; F: flow speed; T: temperature. Results in bold are significant

\begin{tabular}{|lccccc|}
\hline Source & df & SS & MS & $F$ & $p$ \\
\hline Trial & 1 & 0.006 & 0.006 & 9.61 & $\mathbf{0 . 0 0 2}$ \\
I & 1 & 0.000 & 0.000 & 0.29 & 0.59 \\
F & 1 & 0.001 & 0.001 & 1.24 & 0.27 \\
$\mathrm{~T}$ & 1 & 0.021 & 0.021 & 33.72 & $<\mathbf{0 . 0 0 0 1}$ \\
$\mathrm{I} \times \mathrm{F}$ & 1 & 0.001 & 0.001 & 1.90 & 0.17 \\
$\mathrm{I} \times \mathrm{T}$ & 1 & 0.000 & 0.000 & 0.57 & 0.45 \\
$\mathrm{~T} \times \mathrm{F}$ & 1 & 0.002 & 0.002 & 3.22 & 0.07 \\
$\mathrm{I} \times \mathrm{T} \times \mathrm{F}$ & 1 & 0.000 & 0.000 & 0.67 & 0.42 \\
Error & 144 & 0.089 & & & \\
\hline
\end{tabular}

cant because injured corals outgrew uninjured corals in all treatments $(\mathrm{HH}, \mathrm{LH}, \mathrm{LL})$ except the high-flowspeed and low-temperature (HL) treatment (Fig. 1; SNK, $\mathrm{p}<0.05)$, in which corals grew the most (SNK, $\mathrm{p}<$ 0.05). Uninjured corals in the $\mathrm{HH}$ treatment grew less than all corals (SNK, $\mathrm{p}<0.05)$.

The mean $( \pm \mathrm{SE})$ value of $F_{\mathrm{v}} / F_{\mathrm{m}}$ for the freshly collected Pocillopora verrucosa was $0.691 \pm 0.004$ ( $\mathrm{n}=$ $80)$ and $0.648 \pm 0.004(\mathrm{n}=77)$ in Trial 1 and 2 , respectively. Following the incubations, mean $F_{\mathrm{v}} / F_{\mathrm{m}}( \pm \mathrm{SE})$ ranged between $0.558 \pm 0.012$ (LL, predation, Trial 2) to $0.646 \pm 0.016(\mathrm{HH}$, no predation, Trial 2$)$, and differed significantly between trials (Table 3 ); the mean value was higher in Trial 1 than Trial 2. $F_{\mathrm{v}} / F_{\mathrm{m}}$ was also significantly lower in the low-temperature treatment $(0.594 \pm 0.004 ;$ Table 3$)$ than the high-temperature treatment $(0.630 \pm 0.004)$. Relative to the high-temperature treatment, $F_{\mathrm{v}} / F_{\mathrm{m}}$ was more depressed at low temperature in Trial 1 (7\% depression) than Trial 2 (4\% depression).

The extent of lesions ranged in mean area from $74 \pm 4$ to $125 \pm 7 \mathrm{~mm}^{2}$ when they were initially applied, but after $10 \mathrm{~d}$ they had declined in area in all treatment/trial combinations. The mean rate of change in the size of lesions (i.e. 'healing') ranged from $-1.3 \% \mathrm{~d}^{-1}(\mathrm{HH})$ to $-2.5 \% \mathrm{~d}^{-1}$ (LL), and differed significantly between trials $\left(F_{1,78}=20.98, \mathrm{p}<0.0001\right)$, with more rapid healing in Trial $1\left(0.32 \pm 0.06 \% \mathrm{~d}^{-1}\right)$ compared to Trial $2(0.07 \pm$ $\left.0.03 \% \mathrm{~d}^{-1}\right)$. There was no significant influence on healing of flow speed $\left(F_{1,78}=0.19, \mathrm{p}=0.65\right)$, temperature $\left(F_{1,78}=2.97, \mathrm{p}=0.09\right)$, or their interaction $\left(F_{1,78}=0.03, \mathrm{p}=\right.$ $0.87)$. However, there was a nonsignificant trend across both trials for greater healing in the low-temperature than high-temperature treatments (Fig. 2). 


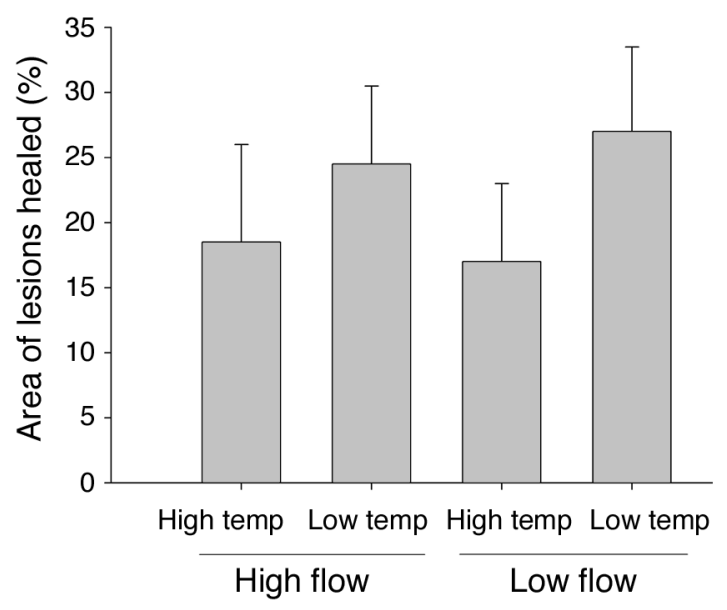

Fig. 2. Pocillopora verrucosa. Mean \% (+SE) of lesions healed at the end of the $10 \mathrm{~d}$ trials; results from the 2 trials are pooled. There was no statistically significant difference among treatments. Corals were the same as described in Fig. 1

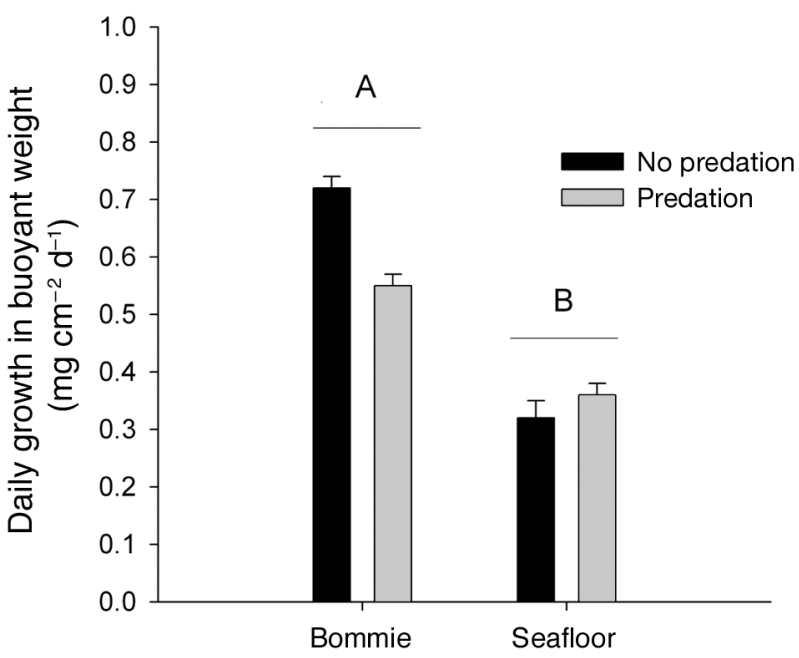

Fig. 3. Pocillopora verrucosa. Growth after $30 \mathrm{~d}$ in the field on top of bommies (high flow; mean speed $14.3 \pm 7.7 \mathrm{~cm} \mathrm{~s}^{-1}$ $[ \pm \mathrm{SE}]$ ) and seafloor (low flow, mean speed $3.2 \pm 2.1 \mathrm{~cm} \mathrm{~s}^{-1}$ ). Corals were placed in either cages (no predation) or cage controls (predation) in both habitats ( $\mathrm{n}=12$ for each bar). A, B: results of SNK $(\mathrm{A}>\mathrm{B}$ at $\mathrm{p}<0.05)$

\section{Field experiment}

All corals survived the $30 \mathrm{~d}$ predator exclusion experiment, but corals were consistently bitten (mostly frequently by butterflyfishes) in the 'predator' treatment ( $\mathrm{H}$. Lenihan pers. obs.). Although we witnessed only one attack by an excavating corallivore-a solitary porcupinefish - by the end of the study, 23 of the 24 corals exposed to corallivores showed distinctive bites characteristic of fish corallivores in the excavating functional group (Bellwood \& Choat 1990). Three
Table 4. Results of a 2-way ANOVA comparing the growth in buoyant weight of juvenile Pocillopora verrucosa as a function of substrate type (bommie versus seafloor), predation (predator exclusion cages versus cage controls in which predators attacked corals), and their interaction. $\mathrm{n}=12$ replicates per treatment. S: substrate; P: predation. Values in bold are significant

\begin{tabular}{|lccccc|}
\hline Source & df & SS & MS & $F$ & $p$ \\
\hline S & 1 & 0.202 & 0.202 & 38.37 & $<\mathbf{0 . 0 0 0 1}$ \\
P & 1 & 0.025 & 0.025 & 4.82 & $\mathbf{0 . 0 3}$ \\
S $\times$ P & 1 & 0.016 & 0.016 & 3.09 & 0.09 \\
Error & 44 & 0.231 & & & \\
\hline
\end{tabular}

of the 23 bitten corals had 2 bite marks, 1 had 3 bite marks, and the remaining 19 had 1 bite mark each; all bites removed the apices of branches, and were 16 to $81 \mathrm{~mm}^{2}$ in size. We do not know how much biomass was removed with each bite, but all affected corals grew. Although these predation events were not witnessed, we believe they were caused by porcupinefish, orange-striped triggerfish, and white-spotted pufferfish, as these corallivores are frequently seen foraging in the study area (H. Lenihan unpubl. data).

Growth rates of Pocillopora verrucosa were higher on the tops of bommies than on the adjacent seafloor (Fig. 3, Table 4; SNK, p < 0.05), and the corals grew more on bommies when protected from corallivores than when unprotected (SNK, p < 0.05). In January 2008 , the mean flow speed on the tops of bommies was $14.3 \pm 2.9 \mathrm{~cm} \mathrm{~s}^{-1}( \pm \mathrm{SE})$, which was significantly higher $\left(F_{1,15}=478.51, \mathrm{p}=0.0001\right)$ than flow speed over the adjacent seafloor $\left(3.4 \pm 1.2 \mathrm{~cm} \mathrm{~s}^{-1}\right)$. During the $24 \mathrm{~h}$ ADV deployment in June 2008, there was a greater frequency of relatively high flow speeds measured on the tops of bommies than on the adjacent seafloor (Fig. 4). There was no significant difference in mean temperatures $\left(F_{1,19}=0.16, \mathrm{p}=0.69\right)$ between treatments (bommies: $27.2 \pm 0.2^{\circ} \mathrm{C}$ versus seafloor: $27.3 \pm$ $1.0^{\circ} \mathrm{C}$ ). For the corals transplanted to the tops of bommies, there was a significant and positive correlation between flow speed and growth in the no predation treatments $(r=0.79, p<0.0001)$ but not in the predation treatments $(\mathrm{r}=0.14, \mathrm{p}>0.09)$.

\section{DISCUSSION}

The present study demonstrates that small colonies of Pocillopora verrucosa are well suited to resisting certain types of physical damage, but that the environment can play an important role in determining the rate of growth and healing in response to this damage. Results of our microcosm experiment indicate that coral growth in response to injuries, executed to mimic 


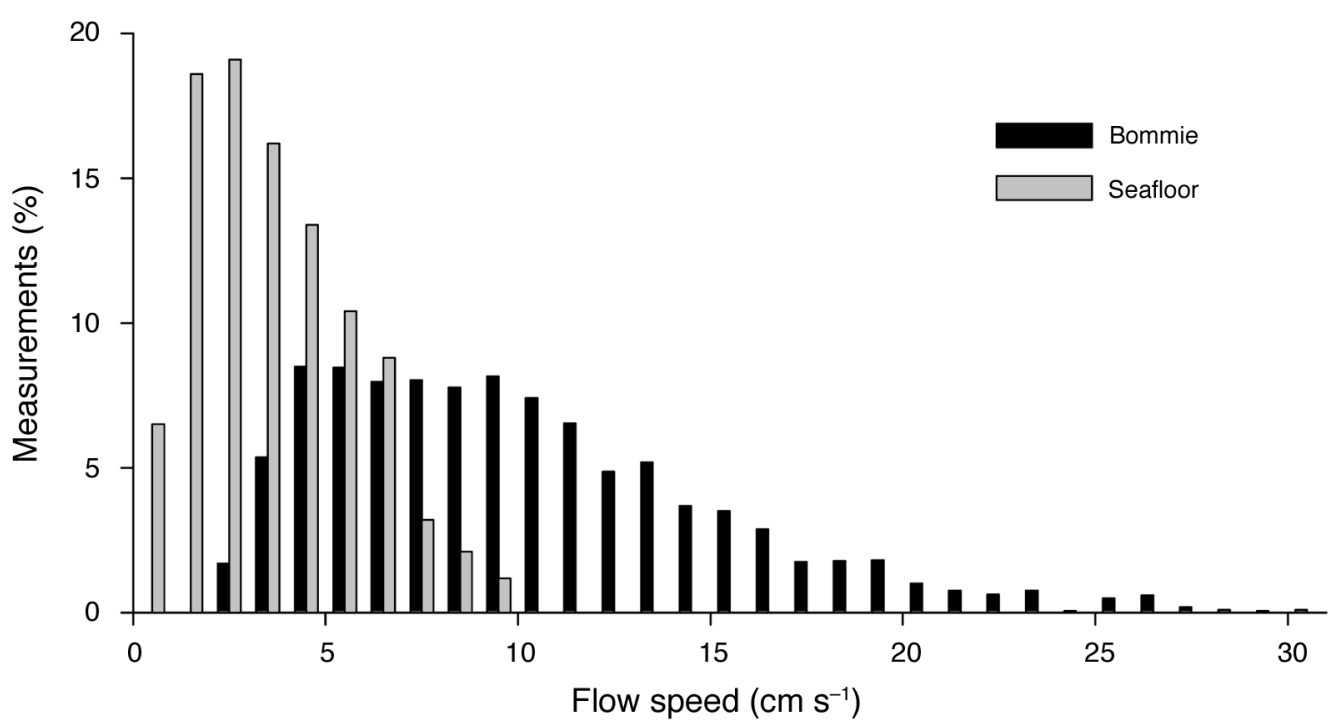

Fig. 4. Flow speeds measured over a coral bommie $(1.1 \mathrm{~m}$ tall) and the adjacent seafloor in June 2008. Data are \% of current speeds measured in the horizontal direction taken over a $24 \mathrm{~h}$ period, with average flow speed calculated every $15 \mathrm{~s}$ (n $=5760$ total measurements per substrate type)

those caused by corallivorous fishes, depended on flow speed and water temperature. In 3 of 4 combinations of flow and temperature, growth rates were higher in corals that had been injured than those that were uninjured. However, highest overall growth occurred in uninjured corals in the high-flow $\left(21 \mathrm{~cm} \mathrm{~s}^{-1}\right)$ lowtemperature $\left(26.6^{\circ} \mathrm{C}\right)$ treatment, which we construe, therefore, to be closer to the optimal conditions for this species, at least relative to the range of treatment conditions employed. The literature suggests that the thermal optimum for Pocillopora growth is close to the lowtemperature treatment $\left(26.6^{\circ} \mathrm{C}\right)$, although it has a wide range $\left(26\right.$ to $\left.31^{\circ} \mathrm{C}\right)$ depending on species and location (Jokiel \& Coles 1977, 1990, Edmunds 2005). Critically, however, the growth of Pocillopora declines at temperatures greater than the threshold value(s), as is true for corals in general (Buddemeier \& Kinzie 1976), and is probably an important factor explaining why growth of uninjured corals in the present study was higher at 26.6 compared to $29.6^{\circ} \mathrm{C}$, at least under high flow. Results for $P$. verrucosa from the microcosm experiment are supported by our field experiment, which demonstrated that growth was greatest for unbitten corals in high flow (and low temperature: $26.6^{\circ} \mathrm{C}$ ), and revealed a trend for elevated growth in injured corals at low flow speeds. Potentially, some of this slight increase in growth at the low flow speed in situ was a result of increased sedimentation under reduced water motion, and it would be productive in future studies to assess the effects of this factor (i.e. sedimentation) on the healing response of corals following corallivory. Importantly, in our field analysis, corals were actually bitten by fish (rather than being subjected to predation simulated by gouging) and sustained damaging bites that were similar in size and characteristics to lesions that we created in the laboratory.

Enhanced growth following simulated biting by excavating fish corallivores may have a strong selective value for a coral with an opportunistic life history strategy, particularly for juvenile life stages. Pocillopora rapidly colonizes open patches of substrate on shallow reefs in the Pacific, and therefore can experience high rates of predation from fish corallivores (e.g. Berumen \& Pratchett 2006). Responding to injury with strong compensatory growth increases the probability that small corals will escape total mortality from predation by growing fast enough to reach a size refuge (Jackson 1977). Growth of individual branches, and potentially their injury or loss, is unlikely to have great biological significance to a coral colony if other branches provide access to nutrients through photosynthesis, particle capture, and beneficial interactions with moving seawater (i.e. to enhance turbulence; Patterson 1992).

One of the striking outcomes of the present analysis is the contrast in growth results for Pocillopora verrucosa relative to the outcome of our companion study with massive Porites (Edmunds \& Lenihan 2010). We hypothesize that the differences between taxa can be attributed to an interaction between morphology and environmentally induced tradeoffs between localized healing and whole colony growth. Whereas the growth of $P$. verrucosa was enhanced by injury under all conditions except high flow and low temperature, for massive Porites growth was only marginally influenced by flow (i.e. $p=0.06$ for the flow $\times$ injury interaction), but 
was strongly affected by the interaction of damage and temperature with the greatest growth in injured corals under high-flow and low-temperature conditions. A priori, we predicted for $P$. verrucosa that injured colonies would grow more slowly than uninjured colonies because their superficial tissues and imperforate skeleton (cf. Porites) limit the capacity for translocating metabolites to wounds and further ensure that the healing of lesions occurs marginally only (i.e. not marginally and basally as in Porites; Edmunds \& Lenihan 2010). This would restrict the capacity for compensatory growth (sensu McNaughton 1983) - achieved through the deposition of new skeleton within the lesion to accomplish regeneration (sensu Henry \& Hart 2005). Our prediction for $P$. verucossa was in part based on the outcomes of our experiment with massive Porites (Edmunds \& Lenihan 2010), in which damage resulted in the highest growth rates, as well as interactive effects between flow and temperature that altered $F_{\mathrm{v}} / F_{\mathrm{m}}$. We attributed these patterns in massive Porites to thick tissue and a perforate skeleton, which increased the likelihood that gouging would leave behind residual tissue and portions of the gastrovascular cavity through which metabolites could be translocated.

We suspect that integration within massive Porites colonies (sensu Oren et al. 2001) is enhanced by thick tissue, which can serve to transport resources to the lesion (e.g. carbon) to facilitate healing and to cause metabolic processes within a lesion (e.g. healing and calcification) to have effects outside the immediate lesion area. These 'integration effects' could have important implications under varying conditions of flow and temperature, which independently and collectively alter metabolic rates (Coles \& Jokiel 1977, Patterson 1992) and can create conditions when metabolic processes are limited by common resources such as $\mathrm{HCO}_{3}{ }^{-1}$. For instance, if low temperatures favor rapid calcification compared to higher temperatures (Jokiel \& Coles 1977), the increased demand of calcification for $\mathrm{HCO}_{3}{ }^{-}$could limit this process through mass transfer limitation (Patterson 1992), which would be alleviated by increased flow (Patterson 1992, Lesser et al. 1994, Nakamura \& Yamasaki 2005). The extent to which calcification might be limited by mass transfer of $\mathrm{HCO}_{3}{ }^{-}$would depend on the reliance of this process on the dissolved inorganic carbon (DIC) content of seawater (versus internal DIC; Allemand et al. 2004). Conceivably, competition between photosynthesis and calcification for limited $\mathrm{HCO}_{3}{ }^{-}$could impact $F_{\mathrm{v}} / F_{\mathrm{m}}$ in a pattern dependent on flow and temperature (as in massive Porites; Edmunds \& Lenihan 2010), although evidence from Stylophora pistillata suggests this might only occur at very low concentrations of $\mathrm{HCO}_{3}{ }^{-1}$ (Furla et al. 2000). Flow can impact corals in more ways than mass transfer alone, and on the reef the patterns impli- cating flow that were detected in a microcosm study would likely be modified through the roles of water motion in modulating the fluxes of zooplanktivorous food (Alldredge \& King 2009) and particle capture rates (Sebens et al. 1998).

The enhancement of growth by injury under most combinations of flow and temperature suggests that Pocillopora verrucosa has a greater relative capacity than massive Porites for compensatory growth (sensu McNaughton 1983), even though it deposits $\mathrm{CaCO}_{3}$ $\left(\sim 0.6 \mathrm{mg} \mathrm{cm}^{-2} \mathrm{~d}^{-1}\right)$ at about half the rate of massive Porites $\left(\sim 1.5 \mathrm{mg} \mathrm{cm}^{-2} \mathrm{~d}^{-1}\right)$. Yet because lesions on $P$. verrucosa can heal only marginally, the compensatory growth in this species is not regenerative per se (sensu Henry \& Hart 2005), rather it must occur over the undamaged colony surface, at the foci of rapid growth (e.g. apical corallites Pearse \& Muscatine 1971), or through reoriented growth (Romano 1990). Determining where on the colony surface the compensatory growth is occurring may be key to understanding the outcome of incubating injured and uninjured $P$. verrucosa under low temperature and high flow. For instance, if compensatory growth occurs on the flanks of the branches under low-flow conditions, then growth could be higher in injured compared to uninjured corals, and under these conditions the effects of temperature might be obscured by mass-transfer limitations. If flow enhances growth on the tips of branches through turbulence near the apices (Chang et al. 2009), and low temperature at high flow accelerates growth because of the proximity of this temperature to the growth optimum (Jokiel \& Coles 1977, 1990, Edmunds 2005), when mass transfer limitation is less likely (Patterson 1992) then growth would be greatest in uninjured branches under high-flow, low-temperature conditions (Fig. 1). Perhaps under these conditions apical growth of injured branches would be impaired by the proximity of apices to the lesion.

The present study, together with our companion study on massive Porites, reveals different responses to fish corallivores that we suspect are caused by morphological differences between the corals. These differences may have functional significance with regard to their life history strategies and the habitats in which they are common. In Moorea, predator-prey interactions between corals and fishes are common (e.g. Berumen \& Pratchett 2006, Schmitt et al. 2009), and in most locations within the lagoon, between 17 and $46 \%$ of juvenile massive and branching corals are found with bite marks, depending on the location and habitat type (H. Lenihan unpubl. data). Massive Porites, like those used in our companion study (Edmunds \& Lenihan 2010), grow in size (i.e. diameter) relatively slowly (Lough \& Barnes 2000), although they deposit $\mathrm{CaCO}_{3}$ at rates (e.g. $\sim 1.6 \mathrm{mg} \mathrm{cm}^{-2} \mathrm{~d}^{-1}$; Edmunds \& Lenihan 


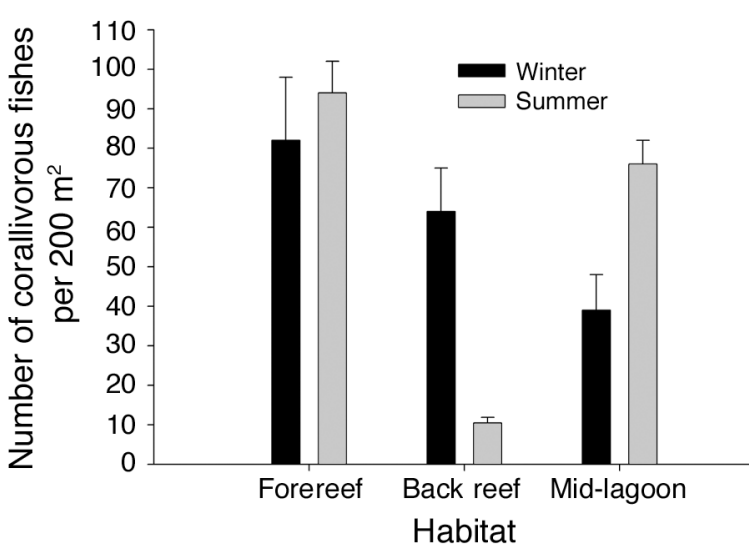

Fig. 5. Mean density $( \pm \mathrm{SE})$ of all corallivorous fishes counted along transect at stations located on the forereef $(6 \mathrm{~m}$ water depth; outside of the lagoon), back reef (in the lagoon; $2 \mathrm{~m}$ depth), and mid-lagoon (near coral experiment; $3 \mathrm{~m}$ depth). $\mathrm{n}=8$ transects sampled at each site in austral summer (January 2008) and winter (July 2008)

2010) faster than Pocillopora verrucosa (present study) and a number of other coral species (Clausen \& Roth 1975, Edmunds 2005). For massive Porites that survive the juvenile stage, subsequent growth can produce exceptionally large colonies (Brown et al. 2009), especially in mid-lagoon and back-lagoon areas, such as those in Moorea, that support relatively few corallivores, at least during seasons when ocean conditions are calm (Fig. 5). In contrast, the back-reef and forereef areas have relatively high densities of Pocillopora (Schmitt et al. 2009), and a relatively high abundance of corallivores, except during seasons when wave size and energy are highest (Fig. 5). Newly settled Pocillopora in these areas depend on their ability to sustain partial predation and grow to a size where they effectively escape the risks of predation. Based on the results of this study and our previous work (Edmunds \& Lenihan 2010), we speculate that the response of corals to fish predation will depend first on the type of damage that fish inflict (Bellwood \& Choat 1990), second on the physical attributes of the environment within which the damage is inflicted, and third on the morphology of the affected corals.

Acknowledgements. This research was supported by grant OCE 04-17412 from the National Science Foundation and gifts from the Gordon and Betty Moore Foundation, and was completed under a research permit issued by the French Polynesian Ministry of Research. We are grateful to N. Davies and the staff of the UC Berkeley, Richard B. Gump South Pacific Research Station for making our visits to Moorea productive and enjoyable, V. Moriarty for technical support, and W. Goldenheim and N. Colvard for field assistance. This is a contribution of the Moorea Coral Reef (MCR) LTER Site, and is contribution number 161 of the Marine Biology Program of California State University, Northridge, and 184 of the Richard B. Gump South Pacific Research Station.

\section{LITERATURE CITED}

Aeby GS, Santavy DL (2006) Factors affecting susceptibility of the coral Montastrea faveolata to black-band disease. Mar Ecol Prog Ser 318:103-110

Alldredge AL, King JM (2009) Near-surface enrichment of zooplankton over a shallow back reef: implications for coral reef food webs. Coral Reefs 28:895-908

Allemand D, Benazet-Tambutte S (1996) Dynamics of calcification in the Mediterranean red coral, Corallium rubrum (Linnaeus) (Cnidaria, Octocorallia). J Exp Zool 276: $270-278$

Allemand D, Ferrier-Pages C, Furla P, Houlbreque F and others (2004) Biomineralization in reef-building corals: from molecular mechanisms to environmental control. CR Palevol 3:453-467

Ayre DJ, Davis AR, Billingham M, Llorens T, Stryan C (1997) Genetic evidence for contrasting patterns of dispersal in solitary and colonial ascidians. Mar Biol 130:51-61

- Barnes DJ, Devereux MJ (1988) Variations in the skeletal architecture associated with density banding in the hard coral Porites. J Exp Mar Biol Ecol 121:37-54

$>$ Bellwood DR, Choat JH (1990) A functional analysis of grazing in parrotfishes (family Scaridae): the ecological implications. Environ Biol Fishes 28:189-214

Belsky AJ, Amundson RG, Duxbury JM, Riha SJ, Ali AR, Mwonga SM (1989) The effects of trees on their physical, chemical and biological environments in a semi-arid savanna in Kenya. J Appl Ecol 26:1005-1024

> Bertness MD, Callaway R (1994) Positive interactions in communities. Trends Ecol Evol 9:191-193

> Berumen ML, Pratchett MS (2006) Recovery without resilience: persistent disturbance and long-term shifts in the structure of fish and coral communities at Tiahura Reef, Moorea. Coral Reefs 25:647-665

> Brown DP, Bash L, Barshis D, Forsman Z, Fenner D, Goldberg J (2009) American Samoa's island of giants: massive Porites colonies at Ta'u island. Coral Reefs 28:735

Buddemeier RW, Kinzie RA (1976) Coral growth. Oceanogr Mar Biol Annu Rev 14:183-225

Cardinale BJ, Burton TM, Brady VJ (1997) The community dynamics of epiphytic midge larvae across the pelagiclittoral interface: Do animals respond to changes in the abiotic environment? Can J Fish Aquat Sci 54:2314-2322

Chang S, Elkins C, Alley M, Eaton J, Monismith S (2009) Flow inside a coral colony measured using a magnetic resonance velocimeter. Limnol Oceanogr 54:1819-1827

Clausen CD, Roth AA (1975) Effect of temperature and temperature adaptation on calcification rate in the hermatypic coral Pocillopora damicornis. Mar Biol 33:93-100

Cole AJ, Pratchett MS, Jones GP (2008) Diversity and functional importance of coral-feeding fishes on tropical coral reefs. Fish Fish 9:286-307

> Coles SL, Jokiel P (1977) Effects of temperature on photosynthesis and respiration in hermatypic corals. Mar Biol 43: 209-216

> Connell JH (1961a) Influence of interspecific competition and other factors on distribution of the barnacle Chthamulus stellatus. Ecology 42:710-732

Connell JH (1961b) Effects of competition, predation by Thais lapillus, and other factors on natural populations of barnacle Balanus balanoides. Ecol Monogr 31:61-92

$>$ Cox EF (1986) The effects of a selective corallivore on growth rates and competition for space between two species of Hawaiian corals. J Exp Mar Biol Ecol 101:161-174

> Crawley ML (1985) Reduction of oak fecundity by low-density herbivore populations. Nature 314:163-164 
Davies PS (1989) Short-term growth measurements of corals using an accurate buoyant weighing technique. Mar Biol 101:389-395

> Dayton PK (1971) Competition, disturbance, and community organization: the provision and subsequent utilization of space in a rocky intertidal community. Ecol Monogr 41: 351-389

> Done TJ (1987) Simulation of the effects of Acanthaster planci on the population structure of massive corals in the genus Porites: evidence of population resilience. Coral Reefs 6: 75-90

Edmunds PJ (2005) The effect of sub-lethal increases in temperature on the growth and population trajectories of three scleractinian corals on the southern Great Barrier Reef. Oecologia 146:350-364

Edmunds PJ (2008) The effects of temperature on the growth of juvenile scleractinian corals. Mar Biol 154:153-162

Edmunds PJ, Lenihan HL (2010) The effect of sub-lethal damage to juvenile colonies of massive Porites under contrasting regimes of temperature and water flow. Mar Biol 157: 887-897

Frydl P (1979) The effect of parrotfish (Scaridae) on coral in Barbados, WI. Int Revue Ges Hydrobiol 64:737-748

Furla P, Galgani I, Durand I, Allemand D (2000) Sources and mechanisms of inorganic carbon transport for coral calcification and photosynthesis. J Exp Biol 203:3445-3457

Gochfeld DJ (2004) Predation-induced morphological and behavioral defenses in a hard coral: implications for foraging behavior of coral-feeding butterflyfishes. Mar Ecol Prog Ser 267:145-158

Hall VR (1997) Interspecific differences in the regeneration of artificial injuries on scleractinian corals. J Exp Mar Biol Ecol 212:9-23

Hall VR (2001) The response of Acropora hyacinthus and Montipora tuberculosa to three different types of colony damage: scraping injury, tissue mortality, and breakage. J Exp Mar Biol Ecol 264:209-223

Henry LA, Hart M (2005) Regeneration from injury and resource allocation in sponges and corals-a review. Int Rev Hydro 90:125-158

Iglesias-Prieto R, Matta JL, Robins WA, Trench RK (1992) Photosynthetic response to elevated temperature in the symbiotic dinoflagellate Symbiodinium microadriaticum in culture. Proc Natl Acad Sci USA 89:10302-10305

> Jackson JBC (1977) Competition on marine hard substrata: the adaptive significance of solitary and colonial strategies. Am Nat 111:743-767

> Jokiel PL, Coles S (1977) Effects of temperature on the mortality and growth of Hawaiian reef corals. Mar Biol 43: 201-208

Jokiel PL, Coles S (1990) Response of Hawaiian and other Indo-Pacific reef corals to elevated temperature. Coral Reefs 8:155-162

Jokiel PL, Maragos JE, Franzisket L (1978) Coral growth: buoyant weight technique. UNESCO Monogr Oceanogr Methodol 5:529-542

- Kramarsky-Winter E, Loya Y (2000) Tissue regeneration in the coral Fungia granulosa: the effect of extrinsic and intrinsic factors. Mar Biol 137:867-873

> Lenihan HS, Peterson CH (1998) How habitat degradation through fishery disturbance enhances effects of hypoxia on oyster reefs. Ecol Appl 8:128-140

Lenihan HS, Adjeroud M, Kotchen MJ, Hench JL, Nakamura $\mathrm{T}$ (2008) Reef structure regulates small-scale spatial variation in coral bleaching. Mar Ecol Prog Ser 370:127-141

Leonard GH, Levine JM, Schmidt PR, Bertness MD (1998) Testing the relative contribution of positive and negative interactions in rocky intertidal communities. Ecology 80:2711-2726

Lesser MP, Weis VM, Patterson MR, Jokiel JP (1994) Effects of morphology and water motion on carbon delivery and productivity in the reef coral Pocillopora damicornis (Linneaeus): diffusion barriers, inorganic carbon limitation, and biochemical plasticity. J Exp Mar Biol Ecol 178:153-179

Lester RT, Bak RPM (1985) Effects of environment on regeneration rate of tissue lesions in the reef coral Montastrea annularis (Scleractinia). Mar Ecol Prog Ser 24:183-185

> Lincoln DE, Fajer ED, Johnson RH (1993) Plant-insect herbivore interactions in elevated $\mathrm{CO}_{2}$ environments. Trends Ecol Evol 8:64-68

> Lough JM, Barnes DJ (2000) Environmental controls on growth of the massive coral Porites. J Exp Mar Biol Ecol 245:225-243

Maxwell K, Johnson GN (2000) Chlorophyll fluorescence-a practical guide. J Exp Bot 51:659-668

McNaughton SJ (1983) Compensatory plant growth as a response to herbivory. Oikos 40:329-336

> Meesters EH, Pauchli W, Bak RPM (1997) Predicting regeneration of physical damage on a reef-building coral by regeneration capacity and lesion shape. Mar Ecol Prog Ser 146:91-99

Moran PJ (1986) The Acanthaster phenomenon. Oceanogr Mar Biol Annu Rev 24:379-480

Motta P (1979) The dentition of seven species of butterflyfish (Chaetodontidae) and their related feeding behavior. Pac Sci 33:123-133

> Nagelkerken I, Meesters EH, Bak RPM (1999) Depth-related variation in regeneration of artificial lesions in the Caribbean corals Porites astreoides and Stephanocoenia michelinii. J Exp Mar Biol Ecol 234:29-39

Nakamura T, Yamasaki H (2005) Requirement of water-flow for sustainable growth of pocilloporid corals during high temperature periods. Mar Pollut Bull 50:1115-1120

> Neudecker S (1979) Effects of grazing and browsing on the zonation of corals in Guam. Ecology 60:666-672

Oren U, Benayahu Y, Lubinevsky H, Loya Y (2001) Colony integration during regeneration in the stony coral Favia favus. Ecology 82:802-813

Paine RT (1966) Food web complexity and species diversity. Am Nat 100:65-83

Patterson MR (1992) A chemical engineering view of cnidarian symbioses. Am Zool 32:566-582

> Pearse VB, Muscatine L (1971) Role of symbiotic algae (zooxanthellae) in coral calcification. Biol Bull 141:350-363

> Peterson CH, Quammen ML (1982) Siphon nipping: its importance to small fishes and its impact on growth of the bivalve Prothaca staminea (Conrad). J Exp Mar Biol Ecol 63:249-268

> Powers SP, Kittinger JN (2002) Hydrodynamic mediation of predator-prey interactions: differential patterns of prey susceptibility and predator success explained by variation in water flow. J Exp Mar Biol Ecol 273:171-187

Powers SP, Peterson CH (2000) Conditional density dependence: the flow trigger to expression of density-dependent emigration in bay scallops. Limnol Oceanogr 45:727-732

$>$ Romano SL (1990) Long-term effects of interspecific aggression on growth of the reef-building corals Cyphastrea ocellina (Dana) and Pocillopora damicornis (Linnaeus). J Exp Mar Biol Ecol 140:135-146

Rotjan RD, Lewis SM (2008) Impact of coral predators on tropical reefs. Mar Ecol Prog Ser 367:73-91

> Rotjan RD, Lewis SM (2009) Predators selectively graze reproductive structures in a clonal marine organism. Mar Biol 156:569-577 
Schmitt RJ, Holbrook SJ, Brooks AJ, Lape JCP (2009) Intraguild predation in a structured habitat: distinguishing multi-predator effects from competitor effects. Ecology 90:2434-2443

Sebens KP, Grace SP, Helmuth BST, Maney EJ, Miles SJ (1998) Water flow and prey capture by three scleractinian corals, Madracis mirabilis, Montastrea cavernosa, and Porites porites, in a field enclosure. Mar Biol 131:347-360

Skilleter GS, Peterson CH (1994) Central foraging behavior of individuals within an ecosystem context: the clam Macoma balthica and interactions between competition and siphon cropping. Oecologia 100:268-278

Stimson J, Kinzie RA (1991) The temporal pattern and rate of release of zooxanthellae from the reef coral Pocillopora damicornis (Linnaeus) under nitrogen enrichment and

Editorial responsibility: Charles Birkeland,

Honolulu, Hawaii, USA control conditions. J Exp Mar Biol Ecol 153:63-74

Strauss SY, Agrawal AA (1999) The ecology and evolution of plant tolerance to herbivory. Trends Ecol Evol 14:179-185

Turner SJ (1994) The biology and population outbreaks of the corallivorous gastropod Drupella on Indo-Pacific reefs. Oceanogr Mar Biol Annu Rev 32:461-530

Titlyanov EA, Titlyanova TV, Yakovleva IM, Nakona Y, Bhagooli R (2005) Regeneration of artificial injuries on scleractinian corals and coral/algal competition for newly formed substrate. J Exp Mar Biol Ecol 323:27-42

Wood R (1998) The ecological evolution of reefs. Annu Rev Ecol Syst 29:179-206

Zajac RN (1985) The effects of sublethal predation on reproduction in the spioned polychaete Polydora ligni (Webster). J Exp Mar Biol Ecol 88:1-19

Submitted: November 9, 2009; Accepted: March 20, 2010

Proofs received from author(s): June 12, 2010 